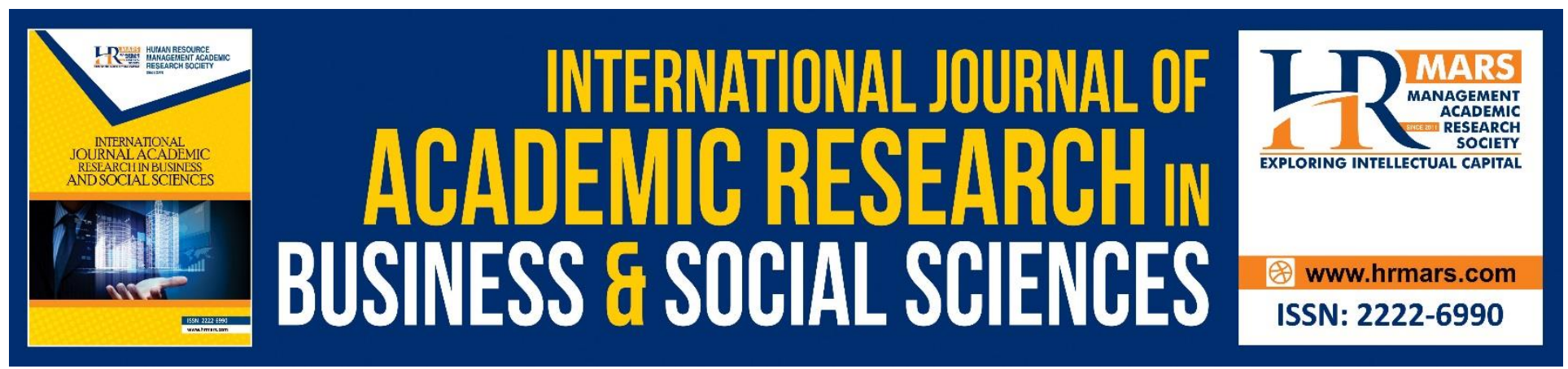

\title{
Shariah Parameters for Conditional Hibah in Preference Shares Structuring
}

\begin{abstract}
Azlin Alisa Ahmad, Siti Mutiara Mohd Azman, Nadhirah Nordin, Salmy Edawati Yaacob
\end{abstract}

To Link this Article: http://dx.doi.org/10.6007/IJARBSS/v10-i11/7928

DOI:10.6007/IJARBSS/v10-i11/7928

Received: 08 September 2020, Revised: 28 September 2020, Accepted: 19 October 2020

Published Online: 09 November 2020

In-Text Citation: (Ahmad, Azman, Nordin, \& Yaacob, 2020)

To Cite this Article: Ahmad, A. A., Azman, S. M. M., Nordin, N., \& Yaacob, S. E. (2020). Shariah Parameters for Conditional Hibah in Preference Shares Structuring. International Journal of Academic Research in Business and Social Sciences. 10(11), 113-122.

Copyright: (C) 2020 The Author(s)

Published by Human Resource Management Academic Research Society (www.hrmars.com)

This article is published under the Creative Commons Attribution (CC BY 4.0) license. Anyone may reproduce, distribute, translate and create derivative works of this article (for both commercial and non-commercial purposes), subject to full attribution to the original publication and authors. The full terms of this license may be seen

at: http://creativecommons.org/licences/by/4.0/legalcode

Vol. 10, No. 11, 2020, Pg. 113 - 122

Full Terms \& Conditions of access and use can be found at http://hrmars.com/index.php/pages/detail/publication-ethics 


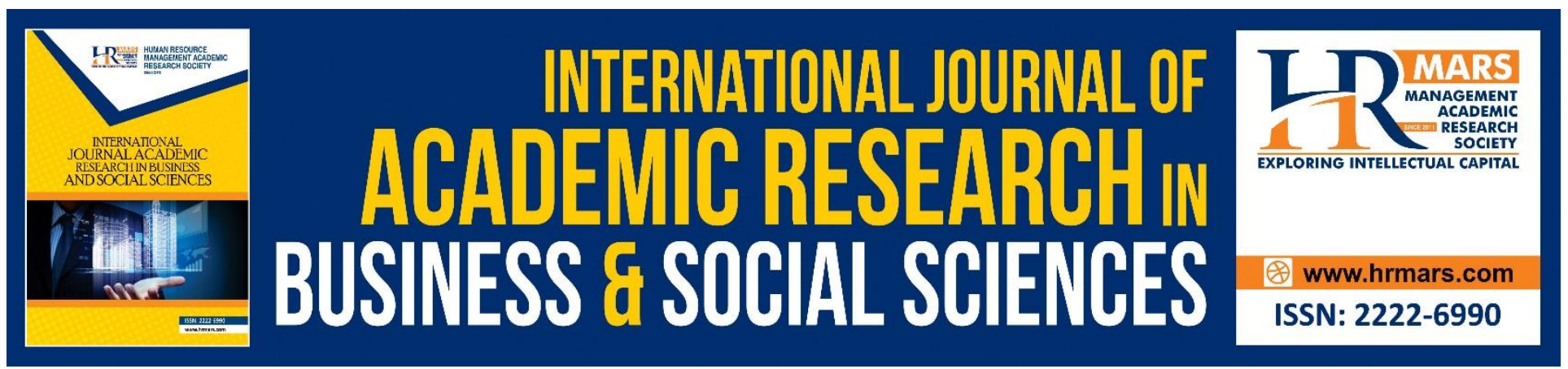

\title{
Shariah Parameters for Conditional Hibah in Preference Shares Structuring
}

\author{
Azlin Alisa Ahmad, Siti Mutiara Mohd Azman \\ Research Centre for Sharia, Faculty of Islamic Studies, Universiti Kebangsaan Malaysia, Bangi. \\ Email: azlinalisa@ukm.edu.my \\ Nadhirah Nordin \\ Fakulti Pengajian Kontemporari Islam, UniSZA Kampus Gong Badak, Terengganu \\ Salmy Edawati Yaacob \\ Research Centre for Sharia, Faculty of Islamic Studies, Universiti Kebangsaan Malaysia, Bangi. \\ Email: salmy1001@ukm.edu.my
}

\begin{abstract}
Preference shares have received a variety of innovations to allow its usage according to the Shariah framework. Among the innovations is the application of tanazul. However, tanazul has sparked controversy following the inherent Shariah issues in the current practice. This article aims to propose suitable shariah parameters for conditional hibah products to be structured in preference shares. This article is a qualitative study, which used the content analysis approach. The findings showed that the Shariah parameters for conditional hibah to be structured in preference shares are: conditional hibah cannot be used for purposes that are conflicting with the Shariah, the preparation of the two contracts of conditional hibah must be done separately, the specified conditions must be the recognized ones and their implementation is feasible, conditional hibah must be based on partners' agreement, the sighah in the first contract must demonstrate elements of promise and binding nature in the future, and the profit determination is in ratio or percentage not in a fixed amount. Therefore, relevant parties should comply with the stipulated Shariah parameters when offering preference share products to Muslim investors. This action can increase the confidence of Muslim investors in the products and indirectly will increase the reputation of the Islamic capital market. This study is critical in order to ensure the Islamic preference shares can compete with the common preference shares. Hence, the construction of specific Shariah parameters for conditional hibah to be structured in preference shares is vital for progressive and more effective implementation that complies with the Shariah requirement.
\end{abstract}

Keywords: Shariah, Parameter, Conditional Hibah, Preference Shares 
INTERNATIONAL JOURNAL OF ACADEMIC RESEARCH IN BUSINESS AND SOCIAL SCIENCES Vol. 10, No. 11, 2020, E-ISSN: 2222-6990 @ 2020 HRMARS

\section{Introduction}

The Shariah provides guidelines for all religious and worldly affairs, including the commercial and civil dealings. The guidelines aim to prevent the occurrence of injustice, which will lead to dispute, gharar, jahalah and maysir and a myriad of businesses that Islam prohibits. The same goes with conditional hibah in preference shares, which is the central focus of this study. It is critical to pay attention to conditional hibah parameters because the usage in preference shares is relatively new. Typically, an innovation in a contract will face various shortcomings and challenges; however, those will be resolved over time and with the ijtihad of scholars in new problems.

Preference share is among the products offered by Islamic Capital Market (ICM) that provides privilege to the stockholders compared to the common stockholders. Generally, preference share is assumed as a hybrid instrument, which combines the characteristics of equity and loan. To date, there is still no specific standard that spells out the status of preference shares whether they must be treated as an equity or a liability. Therefore, preference shares can be categorized as equity or liability or both, depending on the terms and conditions in the agreement.

Meanwhile, conditional hibah is a concept that has great potential and an instrument worthy of being considered to encourage innovations and to increase the flexibility in the structuring of Islamic financial products in the present time (Azman, 2012). Hibah has the potential as a contract in Islamic financial system. The position of hibah as tabarrucat contract causes it to be unaffected by the presence of gharar that can harm mucawadat contract. Hibah is often seen as a solution to some of the inherent problems in the Islamic finance industry in these modern days. A similar situation also occurs in ICM especially in preference shares as they frequently encounter with various problems concerning with Shariah compliancy due to the urge to compromise with the current requirements and innovations that are taking place in the industry. The use of conditional hibah in preference shares must comply with specific parameters to ensure its implementation meets the principles of Shariah as well as free from elements that Islam prohibits such as interest (riba), uncertainty or risk (gharar), gambling (maysir) and others.

This study examined the application of conditional hibah as an appropriate alternative to tanazul. Since conditional hibah is relatively new and the proposal to structure it in preference shares is still in its infancy stage, thus the study on Shariah parameters is necessary because to date, exclusive Shariah parameters for conditional hibah has not yet existed. The conditional hibah concept can probably be used in non-cumulative preference shares in order to encourage innovations and to add flexibility in the products and operation without involving Shariah compliance issues. Therefore, there is a need for a research to develop the Shariah parameters for conditional hibah to be structured in preference shares.

\section{Conditional Hibah Concept}

Hibah is a form of giving that is beneficial to the recipient either in the form of property or nonproperty (Nasrul, et. al 2017). Based on figh terminology, the mazhab scholars have defined hibah in a various manner of utterances. The Hanafi scholars have defined hibah as the giving of ownership of something without expecting a return. According to the Maliki scholars, hibah is the giving of the essence of ownership to the hibah recipient without expecting any form of return. Meanwhile, the Hanbali scholars have defined hibah as the giving of ownership of an existing property by adults that are capable of managing the property while they are still alive, and without any form of exchange (alJaziri, 2003). 
The Shafici scholars have divided the definition of hibah into general and specific terms (al-c Asqalanim 2000; al-Sharbini, 2000). The general definition of hibah refers to the giving of ownership that is consciously performed when one is still alive, which includes charity, gifts and hibah. Meanwhile, the specific definition of hibah refers solely to hibah without involving charity or gifts (al-Jaziri, 2003). Therefore, hibah according to Shafici scholars is the giving of ownership transfer without an expectation for a return to the giver, which is performed voluntarily when the giver is still alive and is subjected to specific tenets (al-Nawawi, 1991; al-Mutici t.th; al-Qalyubi \& 'Umayrah, 1956; alRamli, 2003; al-Ansari, 1998).

From the law perspective, hibah is known as a gift inter vivos, which means a form of a gift of property given to the members of the heir or anyone upon the person's wish, performed voluntarily without expectation of return and the gift is not specified to a particular intention (Nasrul H., 2015). The basis behind the act of hibah centres on one's love for the recipient as a form of aid as well as an appreciation (Muhammad \& Saed, 2015). This definition is derived from the scholars' definitions that hibah is a gift that transfers ownership with the absence of an expectation of return (al-cAyni, 2000; al-Qadiri, 1997; al-Maliki, 1981; al-Nawawi, 2005; Ibn Qudamah, 1994; al-Buhuti, 1983).

Apart from that, some contemporary scholars have defined hibah from the terminological point of view. However, all of the definitions the writers presented contain almost similar meanings, which is hibah is a contract of voluntarily giving the ownership of a property cain without any replacement or return from one party to another while they are still alive (Mohd, 2008; Hazira, 2009; Saed, et. al 2010; Nasrul, 2012; Akmal, 2013). Also, most of the definitions that the contemporary scholars presented also contain meanings that are almost similar with the definition presented by al-Nawawi and al-Sharbini, which is the gift of ownership of something without return that is performed voluntarily and while one is still alive (al-Mutici t.th; al-Sharbini, 2000).

Syarat (condition) is an Arabic origin word that means turning something into an obligation and complying with the obligation (al-Fayruz, 2005). In other words, syarat obliges or binds something that has yet existed upon something that has already existed by the use of specific sighah (al-Hamawi, 1985). When observed, syarat and tacliq share something almost similar, which is the act of attaching or binding something onto something else. This circumstance is caused by tacliq, which is one of the types of condition that can be present in a contract. Therefore, the general syarat covers tacliq, taqyid and idafah (Kamil, 2017).

Based on these definitions, conditional hibah can be concluded as the giving of hibah that is based on a condition or based on tacliq by the occurrence of a circumstance in the hibah contract. In this concept, hibah will only be effective when a specified condition has taken place. In other words, when the specified condition has occurred, then the hibah contract will come into effect. For example, a statement, "if Ahmad comes, I will give this house to you as hibah". Based on the example, when a particular condition occurs, which is "Ahmad comes", the hibah, which is the giving of the house will become valid. On the contrary, if the condition required does not occur, then the hibah will be deemed automatically revoked (al-Khafif, 2008).

Proposed Hibah Parameters in Preference shares

The development of each contract of conditional hibah requires specific dawabit. Therefore, an explicit parameter is vital as the guidelines to ensure the use of conditional hibah in preference shares complies with the Shariah. Generally, the principles of conditional hibah provide an opportunity that can be used in preference shares contract. Nevertheless, a study has to be done to examine how the principles of conditional hibah are structured in preference shares. Thus, it is hoped that the 
INTERNATIONAL JOURNAL OF ACADEMIC RESEARCH IN BUSINESS AND SOCIAL SCIENCES Vol. 10, No. 11, 2020, E-ISSN: 2222-6990 @ 2020 HRMARS

parameters developed can serve as the dawabit to avoid the use of conditional hibah that Shariah prohibits. Among the parameters that must be observed in the use of conditional hibah in preference shares contract are:

a. The purposes for the use must comply with the Shariah

Hibah is a contract that Islam encourages. It is also a contract that belongs in a category known as tabarrucat. Hence, the elements of riba will not affect the tabarrucat contract as riba only exists in mucawadat maliyyah contract. Even though the elements of riba do not affect conditional hibah, yet any activity within the conditional hibah cannot be used for purposes that are against the Shariah or haram such as deceptive riba (Azman, 2012). For example, "If the revenue in the preference shares is less than the expected value, I promise I will give hibah to suffice it." Therefore, it is crucial to ensure that the inclusion of any tacliq or condition in a hibah contract does not alter its original nature from tabarruc to mucawadat. This is because changes in the original nature will corrupt the validity of the contract and the conditions when riba elements are present.

b. The preparation of two contracts must be done separately

Conditional hibah comprises of two conditional contracts that must be prepared separately. Firstly, the agreement to give hibah and secondly; the conditional hibah becomes effective when the conditions specified in the preliminary agreement have already taken place. Therefore, both of the contracts must produce different effects. That is, the first contract is only an agreement between two contracting parties to give hibah of a person's rights in the future, and the agreement shall only bind in the future. On the contrary, the second contract that is the conditions specified in the preliminary agreement have actually occurred, the occurrence prompts the conditional hibah to become effective immediately. Therefore, it means that the giving of hibah takes place when the contract subject exists, which is at the end of the contract. This circumstance also goes along with the hadith لا طلاق إلا فيما تملك ، ولا عتق إلا فيما تملك .

c. The prescribed conditions must be recognized conditions and their implementation is feasible

Conditional hibah uses conditional sighah such as idafah, tawqit and tacliq (Tyabji, 1949). The law of this conditional hibah depends on the status of the prescribed conditions, whether they are permissible (harus) or fasid (Nasrul, 2011). In other words, the prescribed conditions play a pivotal role in ensuring the law of conditional hibah. Therefore, there must be an assurance that the conditions prescribed must be reasonable and recognized by the Shariah. Among others, the conditions allotted in a conditional hibah must be the ones that do not negate the meaning of hibah, which is the giving of property ownership voluntarily (Saed, et. al, 2012). In this study context, the parties involved must perform hibah voluntarily without coercion from others. For example, a common stockholder must willingly give hibah of his ownership to a preference shareholder and vice versa. Therefore, the partners' agreement is crucial to ensure that each party performs the hibah contract voluntarily without being coerced.

Besides, the conditions prescribed must not prevent the recipient from performing tasarruf or any transaction on the property received as hibah (Saed, et. al, 2012). In the context of this study, when a common stockholder has given hibah of the ownership of his or her property to a preference shareholder, thus the preference shareholder has the liberty to perform tasarruf with the property he or she received as hibah. This is because hibah is one of the means for absolute ownership. Therefore, the owner of the property has the freedom to perform transactions that are permissible 
INTERNATIONAL JOURNAL OF ACADEMIC RESEARCH IN BUSINESS AND SOCIAL SCIENCES Vol. 10, No. 11, 2020, E-ISSN: 2222-6990 @ 2020 HRMARS

in Islam (Mohd et.al, 2006). Moreover, the scholars have also ruled that the conditions that prohibit the hibah recipient from performing transactions on the hibah property received as void (Saed, et. al, 2012).

Furthermore, the conditions prescribed must not be the ones considered impossible to occur. In other words, the conditions must be reasonable. Therefore, conditions that are unfeasible or unreasonable will indirectly be void. An example of unreasonable condition in the giving of hibah is for a person to fly into the sky without using any equipment (al-Sharbini 2000). In the context of this study, a prescribed condition that is considered reasonable is the giving of hibah by one party to the other, either the common stockholder or the preference shareholder is a profit is generated or otherwise.

Besides the conditions prescribed must be reasonable, they must also authentically exist. This circumstance concurs with the fundamental of this study, which is based on the hadith of Rasulullah SAW, لا طلاق إلا فيما تملك ، ولا عتق إلا فيما تملك. Therefore, when one of the possibilities takes place, whether profit or loss, the giving of hibah will become effective and binds the parties who are involved in the agreement.

Besides that, the conditions prescribed in conditional hibah must also be the conditions that are aligned with the law and ethics. The setting of conditions that do not respect the law and ethics will cause the conditions to be invalid. An example of such condition is the hibah given by a man to his former wife with the condition that the former wife will not remarry for the rest of her life. In such circumstance, the condition prescribed is void, but the hibah is valid (al-Sharbini, 2000).

\section{d. Partners' agreement is a must}

Partners' agreement is the most crucial aspect that determines the validity of a signed contract. The assurance of the agreement can be derived based on the willingness of the partners to sign a contract. A signed contract will be valid as agreed upon when every partner involved in the signing process has expressed the willingness and agreement with the contract and its conditions. Therefore, if coercion is involved in the signing of the contract, its implementation will not occur.

In Islam, willingness is the core foundation that must be present in all actions to produce certain rights and obligations or to transfer certain rights from a person to another person (al-Khafif, 2008; Abu Zahrah, 1996). The contract shall be implemented when all of the contracting parties are pleased with the conditions prescribed. However, if the contract does not conform to the Shariah, the execution of the contract is still not permissible.

e. The Sighah in the first contract must demonstrate elements of promise and binding nature in the future

Pronouncement adopted in the first contract must show elements of promise and binding nature in the future. An example of such condition is "I promise I will give hibah of my profit when the profit generated in the future is lesser than the profit expected value". The statement shows elements of both conditions because in conditional hibah, the first contract is considered equal to a promise and the promise has a binding nature. This aspect is mentioned in a fiqh method that is بصورة المواعيد لازمة تكون التعاليق, which means promises in the form of tacliq are binding in nature (Azman, 2012). The pronouncement must also contain elements that lead to the act of making hibah contract in the future, not in the present time. The presence of willingness between the two parties is necessary and does not contain any form of coercion whatsoever from any party to undertake such promise. Once 
INTERNATIONAL JOURNAL OF ACADEMIC RESEARCH IN BUSINESS AND SOCIAL SCIENCES Vol. 10, No. 11, 2020, E-ISSN: 2222-6990 @ 2020 HRMARS

the promise has been made, the hibah must be realistically undertaken as agreed in the agreement. The hibah given will result the effect of ownership transfer from a party to another.

Besides, the promise made is also binding, which is any party that has promised to give hibah of his or her rights is obliged and committed to fulfilling his or her promise when the conditions prescribed has actually taken place in the future. In other words, when a circumstance within the conditions in the preliminary agreement has taken place, therefore, the agreed parties must fulfil one's promise to give hibah of one's rights to the other party.

$f$. The determination of profit is in the form of a ratio or percentage, not in the form of a fixed amount.

Generally, a profit is an additional value or return or wage of the capitals and efforts invested by business operators (Louis, 1956). In Arabic, profit is known as al-ribh (Syauqi, 2004), which originated from the term rabiha that means an increase in business activity (Ibn Manzur, n.d.; Abadi, 2005; alZabidi, 1969). Terminologically, profit means an increase of capital as a result of investment activities that are recognized by the Shariah such as businesses, industries and activities alike, which is obtained after the deduction of all the costs involved in the efforts to produce a profit (Shamsiah, 2002).

Similarly, profit is defined as an increase that is produced from the capital through the activities of property exchange from a particular condition to another like buying and selling (Hammad, 2008). Moreover, other scholars stated that a profit is an amount that is produced from the surplus of a capital and expenditure amount after all costs spent have been deducted via the property exchange activities such as businesses, investments, services and others (Ab Rahim, 2012).

The determination of a profit is made at the beginning of a contract (Zuhayli,1985) that is during the promise being bound via an agreement document. The rates of profit and loss specified must be transparent so that each of the partners is aware of his or her rights in the company's earnings (Ibn Qudamah, 1997; al-Kasani, 2003; Ibn Rushd, 1415H). Unclear profit and loss rates will cause the signed contract becoming fasid (al-Khafif, 2009). The distribution of profits must also be based on the nett profits, which is after the deduction of all the company's managerial costs (Khairun, 2013). This is based on the following methods (al-Zaylaci 1315H):

لا ربح إلا بعد سلامة رأس المال

Meaning:

There is no profit until the return of the capital.

The rates for a profit must be in the form of a ratio or percentage (al-Kasani, 2003). The ratio or percentage of a profit must be based on the profit produced not on the ratio of capital contribution by the partners (Khairun, 2013; Darwish, Alzayed, \& Ahmed, 2020). For example, a ratio based on 40:60 or a percentage such as one party receives 40 percent, and the other receives 60 percent (Ibn Qudamah, 1997; Rasyad, 1981). Therefore, the rates of a profit cannot be set in a fixed amount, for example, RM3000, because such practice is against the muqtada caqd and it will nullify the signed contract (Rasyad, 1981; al-Sawi 1990). Nevertheless, the ratio or percentage set must be based on the agreement of all partners.

\section{Conclusion}

This study proposes suitable shariah parameters for conditional hibah products to be structured in preference shares. The recommendation of the application of conditional hibah in preference shares structuring is an alternative solution to tanazul. The purpose of the recommendation is to fulfil the demand of Muslim investors so that the products and the implementation comply with the Shariah 
INTERNATIONAL JOURNAL OF ACADEMIC RESEARCH IN BUSINESS AND SOCIAL SCIENCES Vol. 10, No. 11, 2020, E-ISSN: 2222-6990 @ 2020 HRMARS

principles. Hence, there is a need for a complete Shariah parameter for conditional hibah products in order to serve as the guidelines in ensuring the implementation of the contract conforms with the Shariah principles. The validity and invalidity of conditional hibah status in the structuring of preference shares can also be determined based on the Shariah parameters of conditional hibah recommended. Abandonment of the conditional hibah parameters will corrupt the contract; consequently, the implication is that the abrogation of rights will also not occur between common stockholders and preference shareholders.

Among the parameters recommended are the conditional hibah cannot be used for purposes that are conflicting with the Shariah, the two hibah contracts must be prepared separately, the conditions prescribed must be the recognized ones and their implementation is feasible, the contract must be based on partners' agreement, the sighah in the first contract must demonstrate the elements of promise and binding nature in the future, and the determination of profits must be in the form of ratio or percentage, not in the form of fixed amount. Fundamentally, the argument on the parameters constructed in this article is based on Shariah evidence and experts' opinions. This study also suggests that the conditional hibah in the preference shares structuring to comply with the parameters recommended ensuring the products and their implementation receive Shariahcompliant value. This study also hopes that the suggestion to structure conditional hibah into preference shares can completely fulfil the needs of Muslim investors who need investment products that comprehensively comply with the Shariah principles.

\section{Acknowledgemnt}

The authors would like to thank you to the Ministry of Higher Education Malaysia for funding this research under research grant entitled "Pembinaan Parameter Islamic Swap Dalam Pasaran Derivatif Islam di Malaysia", code project FRGS/1/2018/SS01/UKM/02/5.

\section{References}

Abadi, F. (2005). al-Qamus al-Muhiț. Beirut: Muassasah al-Risalah.

Ab R., I. (2012). Riba dan Ribh Menurut Kewangan Islam: Mekanisme Penentuan Kadar Keuntungan Pembiayaan Jangka Panjang dalam Perbankan Islam. PhD Thesis, Akademi Pengajian Islam, Universiti Malaya.

Abi A. A. (2002). Sahih al-Bukhari. Dimashq \& Beirut: Dar Ibn Kathir.

Abi, S. A. B. (2007). Musannaf li Ibn Abi Syaybah. Jil. 7. al-Qaherah: al-Faruq al-Hadithiyyah li Ṭibacah. Abu, Z. M. (1996). al-Milkiyyah wa Nazariyyat al-cAqd fi al-Sharicah al-Islamiyyah. Qaherah: Dar alFikr al-cArabi.

Ahmad, R. (1960). Mucjam Matan al-Lughah. Jil.5. Beirut: Dar Maktabat al-Hayah.

Akmal, H. M. (2013). Wasiat dan Hibah: Hukum dan Prosedur. Seminar Wanita dan Syariah: Mengurus Harta Bukan Sekadar Merancang Kewangan. Mahkamah Mut, Universiti Islam Antarabangsa Malaysia, 17 November.

Al-Ansari, Z. (1998). Fath al-Wahhab bi Sharh Minhaj al-Ṭullab. Jil. 1. Beirut: Dar al-Kutub al-cllmiyyah. Asaf A. A. F. (1974). Outlines of Muhammadan Law. New Delhi: Oxford University Press.

Al-cAsqalani, A. (2000). Fath al-Bari Sharh Sahih al-Bukhari. Jil. 5. t.tp: al-Maktabah al-Salafiyyah. Al-Ayni, M. A. (2000). al-Binayah fi Sharh al-Hidayah. Jil. 6 \& 10. Beirut: Dar al-Kutub al-Ilmiyyah. 
INTERNATIONAL JOURNAL OF ACADEMIC RESEARCH IN BUSINESS AND SOCIAL SCIENCES

Vol. 10, No. 11, 2020, E-ISSN: 2222-6990 @ 2020 HRMARS

Azman, M. N. (2012). Hibah Mucallaqah (Hibah bertalik) dan Pelaksanaannya di dalam ProdukProduk Kewangan Islam. Muzakarah Penasihat Syariah Kewangan Islam 2012 Kali ke 7 (KLIFF). Inter Continental Hotel, Kuala Lumpur, 15 Oktober.

Al-Bacalbaki, M. (1994). al-Mawrid cArabi Inklizi. Beirut: Dar al-cllm li al-Malayin.

Al-Baji, A. W. S. (1332H). al-Muntaqa Sharh Muwațta' Malik. Jil. 4. Qaherah: Dar al-Kitab al-Islami. Al-Buhuti, M. (1983). Kashshaf al-Qinac can Matn al-lqnac. Jil. 3, 4 \& 5. Beirut: cAlam al-Kutub.

Al-Hamawi, S. A. (1985). Ghamz cUyun al-Basa'ir Sharh Kitab al-Ashbah wa al-Naza'ir. Jil. 4. Beirut: Dar al-Kutub al-cllmiyyah.

Hammad, N. K. (2008). Mucjam al-Musțalahat al-Maliyyah wa al-lqtisadiyyah fi Lughah Fuqaha'. Jeddah: Dar al-Bashir.

Harith, S .F. (1970). Faruqi's Law Dictionary. Beirut: Maktabat Lubnan.

Hazira, R. (2009). Perancangan Harta mengikut Undang-Undang Islam menggunakan Konsep Hibah. Tesis Sarjana, Jabatan Pentadbiran Tanah, Universiti Teknologi Malaysia.

Ibn al-Humam, K. (2003). Sharh Fath al-Qadir cala al-Hidayah Sharh Bidayat al-Mubtadi. Jil. 6 \& 7. Beirut: Dar al-Kutub al-cllmiyyah.

Ibn Manzur, J. (n.d). Lisan al-cArab. Jil. 2, 5, 10 \& 14. Beirut: Dar Sadir.

Ibn Qudamah, M. (1994). al-Kafi. Jil. 2. Beirut: Dar al-Kutub al-cllmiyyah.

Ibn Qudamah, A. M. (1997). al-Mughni. Jil. 6, 7 \& 8. Riyaḍ: Dar cAlam al-Kutub.

Ibn Rushd, M. (1415H). Bidayah al-Mujtahid wa Nihayah al-Muqtasid. Jil. 3 \& 4. Qaherah: Maktabah Ibn Taymiyyah.

Darwish, S., Alzayed, S., \& Ahmed, U. (2020). How Women in Science can Boost Women's Entrepreneurship: Review and Highlights. International Journal of Innovation Creativity and Change, 14(1), 453-470.

Ibn Taymiyyah, S. I. (2004). Majmuc Fatawa Shaykh al-Islam Ibn Taymiyyah. Jil. 29. Madinah: Majmac al-Malik Fahd li Tibacat al-Mushaf al-Sharif.

Ilyas, A. I. (n.d). Elias Modern Dictionary: Arabic-English. Qaherah: Elias Modern Publishing House.

Al-Jaziri, A. R. (2003). Kitab al-Figh cala al-Madhahib al-Arbacah. Jil. 3. Beirut: Dar al-Kutub alcllmiyyah.

Al-Jurjani, A. S. (n.d). Mucjam al-Tacrifat. Qaherah: Dar al-Faḍilah.

Kamus Dewan. (2007). Edisi Ke-4. Kuala Lumpur: Dewan Bahasa dan Pustaka.

Al-Kandahlawi, M. Z. (2003). Awjaz al-Masalik ila Muwațta' Malik. Jil. 9. Dimashq: Dar al-Qalam.

Al-Kasani, A. B. (2003). Bada'ic al-Sana'ic fi Tartib al-Shara'ic. Jil. 4, 6, 7 \& 8. Beirut: Dar al-Kutub alcllmiyyah.

Al-Khafif, A. (2008). Ahkam al-Mucamalat al-Sharicyyah. Qaherah: Dar al-Fikr al-cArabi.

Al-khafif, A. (2009). al-Syarikat fi al-Fiqh al-Islami Buhuth Muqaranah. Qaherah: Dar al-Fiqh al-cArabi.

Khairun, N. S. (2013). Isu-Isu Syariah dalam Sukuk Musyarakah di Malaysia: Kajian terhadap Sukuk yang Diterbitkan dari Tahun 2005 hingga 2010. Master Thesis, Universiti Malaya.

Louis, M. (1956). Al-Munjid fi al-Lughat. Beirut: al-Mațbacah al-Kathulikiyyah.

Al-Maliki, K. (1981). Mukhtasar al-cAllamah Khalil. t.tp: Dar al-Fikr.

Marina, A. B. (2014). Wacd bi al-tanazul dalam amalan saham keutamaan menurut perspektif Islam. Master Thesis, Universiti Kebangsaan Malaysia.

Mohamad, S. (2002). Ciri-Ciri Keuntungan Menurut Perspektif Islam. Jurnal Syariah 10 (1): 121-137

Mohd, K. A. (2017). Hibah berta'liq dan Penggunaannya dalam Takaful: Kajian dari Perspektif Fiqh. PhD Thesis, Akademi Pengajian Islam Universiti Malaya. 
INTERNATIONAL JOURNAL OF ACADEMIC RESEARCH IN BUSINESS AND SOCIAL SCIENCES Vol. 10, No. 11, 2020, E-ISSN: 2222-6990 @ 2020 HRMARS

Mohd Z. M. (2008). Instrumen Hibah: Analisis Hukum dan Aplikasi di Malaysia. Konvensyen Faraid dan Hibah Kebangsaan 2008. Anjuran JAKIM, Dewan Serbaguna, Masjid Wilayah Persekutuan. Kuala Lumpur, 7 Ogos.

Mohd, Z. M., Wafaa, Y., \& Zamzuri, Z. (2006). Konsep Harta dan Kepentingan Pengurusannya Menurut Perspektif Islam. Prosiding Seminar Kebangsaan Pengurusan Harta dalam Islam, hlm. 10.

Saed, M. N. L., Ridzuan, M. A., \& Husin, A. M. N. (2012). Hibah dengan Syarat Balasan Menurut Pandangan Fuqaha dan Kedudukannya dalam Undang-Undang Sivil Jordan. Jurnal Syariah 20(3): 309-328.

Saed, M. N. L., Awang, M. R., \& Nor, M. A. H. (2010). Qabd dan Hukum Penarikan Balik Hibah. Jurnal Muamalat 3: 157-184.

Muhammad, F. A., \& Noor, L. M. S. (2015). Penawaran Produk Hibah Patuh Syariah dalam Industri Perancangan dan Pengurusan Harta Umat Islam di Malaysia. Prosiding Kolokium Antarabangsa Siswazah Pengajian Islam (KASPI) 2015, pp. 37-43.

Muslim, A. H. (2006). Sahih Muslim. Jil. 1. Riyaḍ: Dar Țaybah.

Al-Mutici, M.N. (n.d). al-Majmuc Sharh al-Muhadhdhab li Shirazi. Jil. 9 \& 16. Jeddah: Maktabah alIrshad.

Hisyam, N. M. (2011). Hibah dalam Undang-Undang Islam: Prinsip dan Amalan. Skudai: Penerbit Universiti Teknologi Malaysia.

Nasrul, H. N. M. (2012). Umra dan Ruqba: Analisis Mengenai Kesannya Terhadap Kontrak Hibah dan Potensinya sebagai Instrumen Agihan Harta. Jurnal Syariah 20(1): 1-46.

Al-Nawawi, A. Z. (1991). Rawdat al-Talibin. Jil. 5. Beirut: al-Maktab al-Islami.

Al-Nawawi, M. (2005). Minhaj al-Ṭalibin wa cUmdat al-Muftin. Beirut: Dar al-Minhaj.

Al-Qadiri, M. (1997). Takmilat al-Bahr al-Ra'iq Sharh Kanz al-Daqa'iq. Jil. 7. Beirut: Dar al-Kutub alcllmiyyah.

Al-Qalyubi, S., \& cUmayrah, S. (1956). Hashitan. Jil. 2 \& 3. Mesir: Mustafa al-Babi al-Halabi wa Awladuh.

Al-Ramli, S. M. (2003). Nihayah al-Muhtaj Ila Sharh al-Minhaj. Jil. 4 \& 5. Beirut: Dar al-Kutub alcllmiyyah.

Rasyad, H. K. (1981). al-Sharikat fi Fiqh al-Islami Dirasah Muqaranah. Riyaḍ: Dar Rashid.

Al-Sawi, M. S. M. (1990). Musykilah al-Istithmar fi al-Bunuk al-Islamiyyah. Mansurah: Dar al-Wafa'.

Al-Sharbini, S. (2000). Mughni al-Muhtaj Ila Macrifah Macani al- Alfaz al-Minhaj. Jil. 2, 3 \& 4. Beirut: Dar al-Kutub al-cllmiyyah.

Syauqi D. (2004). al-Mucjam al-Wasiț. Mesir: Maktabah al-Shuruq al-Duliyyah.

Tyabji, K. (1949). Limited Interest in Muhammadan Law. London: Stevens \& Sons Limited.

Al-Zabidi. (1969). Taj al-cArus. Jil. 4 \& 6. Kuwayt: Mațbacat Hukumat al-Kuwayt.

Al-Zaylaci, F. U. (1315H). Tabyin al-Haqa'iq Sharh Kanz al-Daqa'iq. Jil. 4 \& 5. Mesir: Mațbacah al-Kubra al-Amiriyyah.

Zuhayli, W. (1985). al-Fiqh al-Islami wa 'Adillatuhu. Jil. 4 \& 5. Damsyik: Dar al-Fikr. 